\title{
Zakres podmiotowy prawa do petycji w Niemczech
}

\section{Wprowadzenie}

Bodźcem do napisania niniejszego artykułu stały się problemy interpretacyjne w zakresie strony podmiotowej prawa do petycji, powstałe podczas prac Komisji do Spraw Petycji w Sejmie Rzeczypospolitej Polskiej. W Polsce prawo do petycji jest sformułowane w art. 63 Konstytucji Rzeczypospolitej Polskiej ${ }^{1}$. Przepis ten bardzo szeroko określa zakres podmiotowy, przyznając prawo do petycji „każdemu”. Kontrowersje dotyczące tego przepisu odnoszą się między innymi do kwestii, czy organy administracji publicznej mogą składać petycje. W toku prac sejmowej Komisji problem ten pojawił się wtedy, gdy otrzymała ona petycję od wójta gminy w sprawie podjęcia inicjatywy ustawodawczej mającej na celu zmianę prawa podatkowego ${ }^{2}$. Pojawiło się wówczas pytanie, czy gmina lub wójt mogą być autorami petycji. Zdaniem Biura Analiz Sejmowych nie jest to możliwe, ponieważ osobom prawnym prawa publicznego i ich organom nie przysługuje prawo do petycji ${ }^{3}$. Zdanie to znajduje potwierdzenie w polskiej nauce prawa ${ }^{4}$. W praktyce

\footnotetext{
${ }^{1}$ Konstytucja Rzeczypospolitej Polskiej z dnia 2 IV 1997 r. (Dz.U. Nr 78, poz. 483 ze zm.).

2 Zapis przebiegu posiedzenia komisji (nr 67) z dnia 22 III 2017 r., http://www.sejm. gov.pl/sejm8.nsf/biuletyn.xsp?skrnr=PET-67 (dostęp: 17 VI 2018).

${ }^{3}$ S. Pawłowski, Opinia Biura Analiz Sejmowych z dnia 16.01.2017 r. dotyczaca petycji w sprawie podjęcia inicjatywy ustawodawczej majacej na celu doprecyzowanie charakteru dotacji uzdrowiskowej oraz zmiane przepisów prawa podatkowego, która umożliwi skuteczniejszy pobór opłaty uzdrowiskowej, sygn. BAS-WPTK-2736/16, s. 4.

${ }^{4}$ E. Wójcicka, Prawo petycji w Rzeczypospolitej Polskiej, Warszawa 2015, s. 244-246; P. Czarny, Opinia prawna w sprawie dopuszczalności składania petycji przez jednostki samorządu terytorialnego, „Zeszyty Prawnicze BAS” 2017, nr 3(55), s. 57-67.
} 
parlamentarnej jednak petycje tego rodzaju są rozpatrywane pomimo wskazanych kontrowersji.

Ze względu na podobny sposób określenia kręgu osób uprawnionych do składnia petycji w Ustawie Zasadniczej Republiki Federalnej Niemiec (dalej: U.Z.) celem niniejszego opracowania jest ustalenie zakresu podmiotowego prawa do petycji w Niemczech. Szczegółowe przedstawienie tego zagadnienia $\mathrm{z}$ uwzględnieniem bogatego dorobku niemieckiej nauki prawa konstytucyjnego może stanowić przyczynek dokładniejszej analizy wskazanego problemu w Polsce.

Historycznie wszystkie prawa podstawowe zawarte w U.Z. powstały jako narzędzia służące do obrony przed działaniami państwa ${ }^{5}$. W tym zakresie zarówno Federalny Trybunał Konstytucyjny (FTK), jak i Federalny Trybunał Sprawiedliwości (FTS) stoją na stanowisku, że bez wątpienia prawa podstawowe są w pierwszej kolejności stworzone, aby chronić sferę wolności jednostki przed atakami władzy publicznej ${ }^{6}$. Powyższe stwierdzenie odnosi się także do prawa do petycji unormowanego w art. 17 U.Z. Wskazuje się, że prawo to może służyć jako instrument ochrony prawnej ${ }^{7}$, a jego istota sprowadza się do roszczenia jednostki o spełnienie przez państwo świadczenia, jakim jest przyjęcie petycji, rozpatrzenie jej oraz zawiadomienie petenta o sposobie załatwienia sprawy $^{8}$. W tym ujęciu prawo do petycji ma charakter formalny i nie gwarantuje rozstrzygnięcia przez organ sprawy w znaczeniu materialnym ${ }^{9}$. Prawo do petycji, z jednej strony, rodzi zatem uprawnienie jednostki, z drugiej zaś - obowiązek organu. W związku z tym na petycję trzeba spojrzeć w szerszym kontekście jako na instytucję prawną (sensu largo). Wówczas, mówiąc o zakresie podmiotowym, należy wyjść poza krąg podmiotów uprawnionych i wskazać także podmioty zobowiązane do jej załatwienia. Ponadto analiza tytułowego zagadnienia wymaga przedstawienia petycji w jej otoczeniu normatywnym.

${ }^{5}$ I. von Münch, Vorbemerkung zu den Art. 1-19, w: Grundgesetz-Kommentar, Bd. 1, Hrsg. von P. Kunig, München 1992 s. 28.

${ }^{6}$ Orzeczenie FTK z 15 I 1958 r., sygn. 1 BvR 400/51, BVerfGE 7, 198, 204; orzeczenie FTK z 31 X 1974 r., sygn. III ZR 45/72, BGHZ 63, 196, 198.

${ }^{7}$ M. Hornig, Die Petitionsfreiheit als Element der Staatskommunikation, Baden-Baden 2000, s. 64 .

${ }^{8}$ J. Burmeister, Das Petitionsrecht, w: Handbuch des Staatsrechts der Bundesrepublik Deutschland, Bd. 2: Demokratische Willensbildung - Die Staatsorgane des Bundes, Hrsg. von J. Isensee, P. Kirchof, Heidelberg 1987, s. 78.

${ }^{9}$ H. Bauer, Art. 17, w: Grundgesetz-Kommentar, Bd. 1, Hrsg. von H. Dreier, Tübingen 2013, s. 1661. 


\section{Ewolucja historyczna instytucji od supliki do petycji}

Prawa podstawowe unormowane w U.Z. nawiązują do tradycji konstytucjonalizmu niemieckiego XIX w. ${ }^{10} \mathrm{~W}$ związku $\mathrm{z}$ tym, aby poprawnie określić zakres podmiotowy prawa do petycji, warto zwrócić uwagę na historyczny rozwój tej instytucji. Istnienie jej można zaobserwować od czasów rzymskich, kiedy to nazywana supliką, występowała jako prawo poddanych do zwrócenia się do władcy z prośbą lub skarga, która ani nie nadawała nadawcy żadnego specjalnego statusu, ani nie powodowała żadnych zobowiązań adresata ${ }^{11}$. Z biegiem lat instytucja supliki nabrała szerszego charakteru i zaczęto ją adresować nie tylko do cesarza, ale i do parlamentu, sądów cesarskich, poszczególnych panów feudalnych oraz różnych urzędów ${ }^{12}$. Omawiana instytucja pod nazwą petycja znana jest dopiero od XIX w., kiedy to procesy społeczne doprowadziły do zmiany poddanych w obywateli, a supliki w petycję ${ }^{13}$. Zmiana ta nie była jedynie semantyczna. Nowo nabyta świadomość kształtujących się zalążków społeczeństwa obywatelskiego odcisnęła swoje piętno także na charakterze omawianej instytucji, która straciła swoja pozycję jako środek ochrony prawnej, a w to miejsce urosła do rangi instytucji politycznej partycypacji obywateli, uzupełniającej prawa wyborcze ${ }^{14}$.

\subsection{Konstytucja Cesarstwa Niemieckiego z 1849 r.}

Proces powstawania społeczeństwa obywatelskiego znalazł swoje odzwierciedlenie w Konstytucji Cesarstwa Niemieckiego z 1849 r., nazywanej też konstytucją frankfurcką. Akt ten, pomimo że nigdy nie wszedł w życie, uznaje się za pierwszą demokratyczną konstytucję Niemiec, która pod wieloma względami była niezwykle nowoczesna. W rozdziale zatytułowanym "Prawa podstawowe narodu niemieckiego" w § 159 gwarantował on prawo do petycji, stanowiąc w ust. 1, że każdy Niemiec ma prawo zwrócić się pisemnie z prośbą lub skargą do organu, przedstawicielstw narodu lub do parlamentu cesarstwa. Przepis ten

${ }^{10}$ I. von Münch, op. cit., s. 19.

${ }^{11}$ H. Klein, Art. 17, w: Grundgesetz-Kommentar, Bd. 1, Hrsg. von R. Herzog, R. Scholz, M. Herdegen, H. Klein, München 2017, Nb. 4.

12 H. Bauer, Art. 17, s. 1634.

${ }^{13}$ M. Hornig, op. cit., s. 23.

${ }^{14}$ Ibidem, s. 32-37. 
wprowadzał nowatorskie spojrzenie na petycję, uznając ją nie tylko za prawo indywidualne jednostki zgodnie $z$ ust. 1 , ale także za prawo kolektywne, wskazując w ust. 2, że prawo to może być wykonywane zarówno przez jednostkę, jak i korporacje oraz większą liczbę osób zrzeszonych w stowarzyszeniach. Przepis ten wprowadzał także ograniczenia podmiotowe, stanowiąc, że petycje w siłach zbrojnych mogą być przedkładane jedynie w sposób zgodny $\mathrm{z}$ istniejącymi przepisami dyscyplinarnymi. W piśmiennictwie wskazuje się, że uznanie petycji za prawo zbiorowości, a nie tylko jednostki było efektem zmiany sposobu myślenia o instytucji petycji. Przestano utożsamiać petycje o charakterze politycznym za zagrożenie dla stabilności władzy. Zauważono, że petycje w wymiarze zbiorowym mogą stanowić swego rodzaju wentyl bezpieczeństwa, dzięki któremu można złagodzić nastroje społeczne ${ }^{15}$.

\subsection{Konstytucja Cesarstwa Niemieckiego z 1871 r.}

Kolejnym etapem unormowań konstytucyjnych prawa do petycji na terenach dzisiejszej Republiki Federalnej Niemiec był art. 23 Konstytucji Cesarstwa Niemieckiego z 1871 r., który stanowił, że Reichstag w granicach kompetencji cesarstwa ma prawo przekazywać rządowi petycje zaadresowane do Reichstagu. Sporna, pośród ówczesnych komentatorów, była kwestia, czy w kontekście art. 23 można mówić o publicznym prawie podmiotowym. Jedni potwierdzali tę tezę, wskazując, że z prawem do petycji jednostki koresponduje obowiązek odebrania i rozpatrzenia petycji ${ }^{16}$. Inni stwierdzali, że przepis ten nie ustanawiał żadnego uprawnienia jednostki do składnia petycji, ale jedynie uprawnienie parlamentu do przekazywania petycji rządowi. Możliwość składania petycji przez jednostkę traktowali jako kwestię oczywistą, która nie wymagała żadnych dodatkowych gwarancji ${ }^{17}$. C. Bornhak pisał, że prawo do petycji jest tak oczywiste jak jedzenie lub spanie, a w związku z tym nie należy nadawać mu szczególnego statusu prawa podmiotowego ${ }^{18}$. Petycję postrzegano jako instytucję, za pomocą

\footnotetext{
${ }^{15}$ Ibidem, s. 37.

${ }^{16}$ H. Klein, op. cit., Nb. 13.

${ }^{17}$ M. Hornig, op. cit., s. 42.

${ }^{18}$ C. Bornhak, Das Petitionsrecht, "Archiv des öffentlichen Rechts” 1901, Nr. 16, s. 405.
} 
której parlament ma możliwość sprawowania kontroli nad rządem $\mathrm{w}$ interesie publicznym. W związku z tym zadaniem adresata petycji rozpatrującego skargi lub wnioski było zaspokojenie w pierwszej kolejności interesu publicznego, który został unaoczniony poprzez daną petycję. Interes osoby składającej petycję schodził w takim przypadku na plan dalszy ${ }^{19}$.

\subsection{Konstytucja Republiki Weimarskiej z 1919 r.}

Dalszy rozwój omawianej instytucji nastąpił po I wojnie światowej z chwilą uchwalenia konstytucji weimarskiej (KW) z 1919 r. Akt ten w zakresie zawartego w nim katalogu praw podstawowych wyraźnie nawiązywał swoim kształtem do konstytucji z 1849 r. ${ }^{20}$ Artykuł 126 KW stanowil, że każdy Niemiec ma prawo zwrócić się pisemnie z prośbą lub skargą do właściwego urzędu albo do przedstawicielstwa narodu oraz że prawo do petycji może być wykonywane zarówno jednoosobowo, jak i wspólnie z innymi. Wskazuje się, że powyższy przepis wyraźnie już kształtował prawo do petycji jako publiczne prawo podmiotowe, które uprawnia do żądania od państwa podjęcia określonego działania lub jego zaniechania ${ }^{21}$.

Powstały jednak pewne kontrowersje w stosunku do zakresu podmiotowego art. $126 \mathrm{KW}$. Część komentatorów porównywała prawo do petycji do ludowej inicjatywy ustawodawczej i zaliczała je do demokratycznych praw obywateli ${ }^{22}$. Inni, pomimo że art. $126 \mathrm{KW}$ wskazywał wyraźnie, iż prawo do składania próśb i skarg przysługuje każdemu Niemcowi, podnosili, że przysługuje ono także obcokrajowcom. Zwolennicy tego poglądu wywodzili swoje przekonanie z pierwotnej formy petycji, którą była suplika mająca charakter swego rodzaju generalnego środka zaskarżenia. Stali oni na stanowisku, że analizowane uprawnienie nie ma charakteru obywatelskiego, z którym utożsamiano udział $\mathrm{w}$ procesie podejmowania decyzji w państwie ${ }^{23}$. Jednym z takich komentatorów był J. Hatschek. Zdaniem tego autora

\footnotetext{
${ }^{19}$ H. Klein, op. cit., Nb. 12.

${ }^{20}$ M. Hornig, op. cit., s. 46.

${ }^{21}$ Ibidem, s. 48.

${ }^{22}$ H. Klein, op. cit., Nb. 16.

${ }^{23}$ Ibidem.
} 
prawo do petycji przysługiwało mieszkańcom i nie można było nadawać mu charakteru stricte politycznego. W związku z tym wywodził on, że prawo to przysługuje nie tylko osobom posiadającym prawa wyborcze, ale także osobom niepełnoletnim oraz obcokrajowcom zamieszkałym na terenie Cesarstwa Niemieckiego. Ponadto wskazywał, że Reichstag nie był organem odwoławczym, który stałby na straży praw i interesów petentów. Twierdził też, że parlament cesarstwa, rozpatrując petycję, działa we własnym interesie. Przyjmując skargę lub prośbę do rozpatrzenia, mógł on wybrać z niej jedynie te elementy, które służą interesom parlamentu. W związku z takim postrzeganiem petycji nic nie stoi na przeszkodzie, aby zakres podmiotowy prawa do petycji był bardzo szeroki i żeby parlament mógł przyjmować petycje nawet od obcokrajowców zamieszkałych na stałe za zagranicą czy osób zamieszkałych w niemieckich koloniach ${ }^{24}$. J. Hatschek podobnie wypowiadał się w stosunku do gmin oraz szeroko rozumianych instytucji prawa publicznego lub prywatnego, wskazując, że powinny one mieć nieograniczone prawo do składania petycji. Nieposiadanie osobowości prawnej przez różnego rodzaju stowarzyszenia też nie powinno być kwestią dyskwalifikująca, gdyż składane przez nie petycje można zakwalifikować jako petycje zbiorowe. Cytowany autor rozważał też możliwość składania petycji przez urzędników. Zwracał uwagę, że konstytucja weimarska w art. 130 ust. 2 gwarantuje im wolność poglądów politycznych. Wychodząc z tego założenia, stwierdzał, że śmieszne byłoby zapewnienie wolności poglądów politycznych, które można wygłaszać jedynie w zaciszu własnego domu. W związku z tym stwierdzał też, że musi być zagwarantowana możliwość swobodnego wygłaszania własnych poglądów przez urzędników również poprzez składanie petycji ${ }^{25}$. Kwestia ta szeroko dyskutowana była ówcześnie w parlamencie w kontekście podpisania petycji zbiorowej przez dwóch urzędników pocztowych ${ }^{26}$. Właściwe ustawy nakładały jednak ograniczenia w przedkładaniu petycji przez urzędników i żołnierzy, nie negując jednocześnie faktu, że prawo do petycji przysługiwało także im, tak samo jak każde inne prawo zagwarantowane przez konstytucję ${ }^{27}$.

\footnotetext{
${ }^{24}$ J. Hatschek, Deutsches und preussisches Staatsrecht, Bd. 2, Berlin 1922, s. 249.

${ }^{25}$ Ibidem, s. 250.

${ }^{26}$ Ibidem, s. 251-252.

${ }^{27}$ H. Klein, op. cit., Nb. 19.
} 


\section{Prawo do petycji w Ustawie Zasadniczej z 1949 r.}

Po II wojnie światowej, pomimo pojawiających się głosów wskazujących, że prawo do petycji jest zbędną instytucją ${ }^{28}$, utrzymano jej rangę konstytucyjna, zamieszczając w U.Z. art. 17. W myśl tego przepisu „Każdy ma prawo indywidualnie lub wspólnie z innymi do zwracania się z pisemnymi prośbami lub zażaleniami do właściwych organów i do przedstawicielstwa narodu". Kształt tego przepisu w dużej mierze nawiązuje do rozwiązań przyjętych przez konstytucję weimarską z 1919 r. W zakresie strony podmiotowej, formułując treść art. 17 U.Z., wprowadzono jednak znaczące zmiany w porównaniu z poprzednią konstytucją. Wskazuje się, że oznaczenie podmiotu prawa do petycji w art. 17 za pomocą słowa "każdy" było motywowane maksymalnym rozszerzeniem zakresu uprawnionych tak, aby już bez żadnych wątpliwości prawo to $\mathrm{w}$ rzeczywistości przysługiwało nie tylko Niemcom ${ }^{29}$. Zamiana słowa urząd (die Behörde) na właściwy organ (die zuständigen Stellen), które inspirowane było angielskim słowem agency, tłumaczono możliwością rozszerzenia zakresu adresatów także na organizacje międzynarodowe, do których może należeć w przyszłości RFN ${ }^{30}$. W pracach komisji nad art. 17 U.Z. pojawiły się głosy, żeby prawo do petycji umieścić pośród praw obywatelskich, nadając mu obywatelski charakter. Propozycja ta nie została jednak ujęta w ostatecznym projekcie U.Z. ${ }^{31}$

Prawo do petycji, jako jedno z najbardziej podstawowych praw w demokratycznym państwie, zostało tak skonstruowane, aby umożliwić jak najłatwiejszy kontakt szerokiej grupie podmiotów z organami państwa. Osiągnięto to za pomocą minimalnych obwarowań formalnych ${ }^{32}$. Zgodnie z art. 17 U.Z. petycja musi mieć formę pisemna, co jest jedynym wymogiem formalnym zamieszczonym w tym przepisie. Forma pisemna w rozumieniu art. 17 U.Z. nie jest jednak rozumiana wyłącznie jako własnoręczny podpis na wystawianym dokumencie. Petycja może być złożona także w formie elektronicznej, np. w postaci zwykłego e-maila ${ }^{33}$.

${ }^{28}$ H. Bauer, $\$ 117$ Petitionsrecht, w: Handbuch der Grundrechte in Deutschland und Europa, Bd. 5: Grundrechte in Deutschland: Einzelgrundrechte II, Hrsg. von D. Merten, H. Papier, Heidelberg 2013, s. 414.

${ }^{29}$ H. Klein, op. cit., Nb. 22.

${ }^{30}$ Ibidem.

${ }^{31}$ Ibidem, Nb. 23-24.

32 J. Burmeister, op. cit., s. 84 .

${ }^{33}$ A. Guckelberger, Neue Erscheinungen des Petitionsrechts: E-Petitionen und öffentliche Petitionen, "Die Öffentliche Verwaltung” 2008, Nr. 3, s. 87. 
Celem wymogu zachowania formy pisemnej petycji jest, jak podnosi się w doktrynie prawa, z jednej strony konieczność ustalenia rzeczywistego zamiaru złożenia petycji przez petenta ${ }^{34}$, a z drugiej - sprawność postępowania $^{35}$. Ze względu na to wyklucza się też możliwość składania petycji anonimowych ${ }^{36}$.

Należy zauważyć, że art. 17 U.Z. nie zawiera w swojej treści słowa petycja. Zamiast tego stanowi on o "prośbie" lub "skardze”. W związku z tym przy określeniu zakresu przedmiotowego brak jest problemów interpretacyjnych znanych z polskiego ustawodawstwa, gdzie w art. 63 Konstytucji RP obok siebie wymienia się petycje, wnioski i skargi, co może sugerować, że te trzy słowa wskazują na odmienne czynności, których zakres się wzajemnie wyklucza ${ }^{37}$. Zgodnie z piśmiennictwem niemieckim pojęcie petycji jest terminem zbiorowym zawierającym w sobie zarówno prośby, jak i skargi. Petycje, które przyjmują postać skargi, będą odnosiły się do zdarzeń przeszłych i mogą być traktowane jako różnego rodzaju nieformalne zażalenia, odwołania lub zarzuty, które nie są zagwarantowane przez art. 19 ust. 4 U.Z. w ramach prawa do sądowej kontroli działalności władzy wykonawczej ${ }^{38}$. Treścią prośby mogą być natomiast wnioski o podjęcie przez władzę publiczną jakiegoś działania na przyszłość, np. w formie inicjatywy ustawodawczej.

Fakt, że petycja może być użyta zarówno w indywidualnym przypadku dotyczącym sytuacji petenta, jak i osoby trzeciej oraz w kwestiach ogólnospołecznych, sprawia, iż instytucja ta jest niezwykle wszechstronna. Dodatkowo brak rygorystycznych wymagań formalnych przyczynia się do skrócenia dystansu pomiędzy jednostką a organami władzy publicznej. Oczywiście, taka forma ma też swoje mankamenty, które w literaturze przedmiotu materializują się stwierdzeniami, że instytucja petycji jest to narzędzie nieposiadające formy ani terminu, $\mathrm{w}$ jakim musi być załatwiona, w konsekwencji czego jest bezowocna ${ }^{39}$.

${ }^{34}$ T. Gerner, Das Petitionsrecht nach Artikel 17 des Grundgesetzes, „Neue Zeitschrift für Sozialrecht" 2012, Nr. 22, s. 849.

${ }^{35} \mathrm{~J}$. Burmeister, op. cit., s. 84.

${ }^{36}$ L. Brocker, Art. 17, w: BeckOK Grundgesetz, Hrsg. von V. Epping, C. Hillgruber, München 2017, Nb. 14.

${ }^{37}$ W. Sokolewicz, K. Wojtyczek, Art. 63, w: Konstytucja Rzeczypospolitej Polskiej. Komentarz, t. 2, pod red. L. Garlickiego, M. Zubika, Warszawa 2016, s. 554.

${ }^{38}$ G. Krings, Die Petitionsfreiheit nach Art. 17 GG, "Juristische Schulung" 2004, Nr. 6, s. 476.

${ }^{39}$ H. Bauer, Das Petitionsrecht: Eine Petitesse? Zugleich ein Beitrag zum Institut des Öffentlichen Petition, w: Der grundrechtsgeprägte Verfassungsstaat. Festschrift für Klaus Stern zum 80. Geburtstag, Hrsg. von M. Sachs, H. Siekmann, Berlin 2012, s. 1213. 


\section{Adresat petycji jako podmiot zobowiązany}

Przepis art. 17 U.Z. stanowi, że petycja może być adresowana do właściwych organów (Zuständige Stellen) lub do przedstawicielstwa narodu (Volksvertretung). Słowo die Stelle, które można przetłumaczyć na język polski jako organ lub miejsce, w tym kontekście nie oznacza jedynie organu w znaczeniu stricte administracyjnoprawnym. Sformułowanie to definiuje się bardzo szeroko, wskazując, że określa ono każdą jednostkę działającą na podstawie prawa publicznego ${ }^{40}$. W związku z tym w rozumieniu tego przepisu jako właściwe organy należy rozumieć całą władzę publiczną, która jest związana, zgodnie z art. 1 ust. 3 U.Z., obowiązkiem przestrzegania praw podstawowych. Pojęcie to obejmuje zarówno organy federalne, jak i organy poszczególnych krajów związkowych. Także sądy mogą być adresatami petycji w zakresie zadań z zakresu administracji publicznej, które nie są przedmiotem toczących się postępowań sądowych ${ }^{41}$. W tym kontekście nie ma znaczenia forma prawna i organizacyjna adresata petycji. Można ją kierować również do instytucji powstałych na podstawie prawa prywatnego. Jako przykład można podać spółki prawa handlowego, za pomocą których, w ramach tzw. prywatyzacji zadań publicznych, państwo wykonuje swoje zadania ${ }^{42}$.

Organ jest właściwy, gdy ma możliwość zgodnie ze swoimi kompetencjami i zadaniami podjać jakiekolwiek działania w materii wskazanej w treści petycji. Z kolei na organie, który nie jest właściwy do rozpatrzenia petycji, ciąży obowiązek przesłania petycji do właściwego adresata i zawiadomienie o tym petenta ${ }^{43}$.

Drugą kategorią podmiotów, do których petent może się zwrócić, są przedstawicielstwa narodu. Pod tym pojęciem kryje się zarówno Bundestag, jak i parlamenty poszczególnych krajów związkowych, a także samorządowe organy przedstawicielskie ${ }^{44}$. Jednocześnie należy wskazać, że adresatami nie są członkowie tych organów. Możliwe jest natomiast przedłożenie petycji konkretnemu parlamentarzyście lub klubowi parlamentarnemu, który jest zobowiązany przekazać ją do odpowiedniego organu. Powyższe zobowiązanie nie stanowi naruszenia zasady

${ }^{40}$ C. Coelln, Art. 17, w: Grundrechte-Kommentar, Hrsg. von K. Stern, F. Becker, Köln 2016, s. 1329.

${ }^{41}$ L. Brocker, op. cit., Nb. 19.

${ }^{42}$ Ibidem, nb. 18-18.1.

${ }^{43}$ C. Coelln, op. cit., s. 1330.

${ }^{44}$ Ibidem, s. 1328. 
wolnego mandatu parlamentarnego zagwarantowanego przez art. 38 ust. 1 U.Z. ${ }^{45} \mathrm{~W}$ odróżnieniu od pierwszej kategorii adresatów ustawodawca nie użył przymiotnika "właściwy”, wskazując organy przedstawicielskie jako adresatów petycji. W związku z tym można by przyjąć domniemanie ogólnej właściwości Bundestagu co do każdego rodzaju petycji. W literaturze przypomina się jednak, że organy przedstawicielskie działają na dwóch poziomach, tj. federalnym i związkowym, co przekłada się na ich zakres kompetencyjny ${ }^{46}$. Parlament w tym zakresie nie musi mieć wskazanych wyraźnych kompetencji do rozpatrywania konkretnego rodzaju petycji, tak jak ma to miejsce w przypadku właściwych organów. Dlatego w literaturze mówi się o formalnej ogólnej właściwości Bundestagu do rozpatrywani petycji, która będzie ograniczona do możliwości odebrania petycji oraz jej rozpatrzenia. Jednakże kompetencje do ostatecznego rozstrzygnięcia zagadnienia sformułowanego w konkretnej prośbie lub skardze są ograniczone ze względu na federalny charakter państwa niemieckiego oraz na trójpodział władzy. W tym zakresie parlament dysponuje jedynie możliwością politycznego oddziaływania na rząd i organy administracji ${ }^{47}$. W tym kontekście negowana jest jednoznacznie całkowita ogólna właściwość Bundestagu lub parlamentów krajów związkowych w zakresie wszystkich petycji, bez rozróżniania na ich temat oraz rodzaj ${ }^{48}$.

Zarówno Bundestag, jak i parlamenty poszczególnych krajów związkowych mają wewnętrzne organy, tj. komisje, których zadaniem jest merytoryczne załatwienie petycji. To na nich spoczywa główny ciężar pracy nad rozpatrywaniem próśb i zażaleń kierowanych do tych instytucji. Choć historycznie instytucja specjalnej komisji, której zadaniem jest odciążanie prac parlamentarnych w omawianym zakresie, jest znana w Niemczech od średniowiecza ${ }^{49}$, to dopiero w 1975 r., z chwilą uchwalenia art. 45c U.Z., byt Komisji do Spraw Petycji został unormowany na poziomie konstytucyjnym. W myśl tego przepisu Bundestag obowiązany jest powołać komisję petycyjna, do której obowiązków, zgodnie z art. 17, należy rozpatrywanie próśb i zażaleń kierowanych

\footnotetext{
${ }^{45}$ J. Burmeister, op. cit., s. 95.

${ }^{46}$ G. Krings, op. cit., s. 477.

${ }^{47}$ C. Coelln, op. cit., s. 1328.

${ }^{48}$ J. Krüper, Bürgerschaftlicher Einfluss auf das Parlament, w: Parlamentsrecht, Praxishandbuch, Hrsg. von M. Morlok, U. Schliesky, D. Wiefelspütz, Baden-Baden 2016, s. 1127.

${ }^{49}$ H. Bauer, Art. 45c, w: Grundgesetz-Kommentar, Bd. 2, Hrsg. von H. Dreier, Tübingen
} 2015, s. 1273. 
do Bundestagu. Powyższe unormowanie powołuje do życia Komisję do Spraw Petycji jako jedną z czterech stałych komisji w Bundestagu, obok Komisji do spraw Unii Europejskiej (art. 45 U.Z.) oraz Komisji Spraw Zagranicznych i Komisji Obrony (art. 45a U.Z.). Celem dodania art. 45c U.Z. była poprawa pozycji prawnej Komisji do Spraw Petycji, której status prawny wynikał jedynie z regulaminu Bundestagu ${ }^{50}$. Na skutek tej zmiany dokonano nie tylko konstytucjonalizacji tego organu wewnętrznego, ale także postanowiono, że kompetencje komisji określi ustawa federalna. W związku z tymi postanowieniami Ustawa z dnia 19 lipca 1975 r. o uprawnieniach Komisji do Spraw Petycji Bundestagu ${ }^{51}$ określa kompetencje analizowanego organu. Z kolei skład komisji normuje regulamin Bundestagu. Pomimo jej konstytucjonalizacji i poddania regulacji ustawowej nadal pozostaje ona wewnętrznym organem Bundestagu, prowadząc jedynie prace przygotowawcze. Ostateczna decyzja co do sposobu rozpatrzenia petycji pozostaje każdorazowo w rękach parlamentu ${ }^{52}$.

Jak już wspomniano, prawo do petycji tworzy po stronie organu, do którego została wniesiona petycja, pewne obowiązki. Podstawowym jest nietworzenie sytuacji lub procedur, które utrudniałyby lub uniemożliwiały petentowi zbieranie podpisów lub wniesienie petycji. Między innymi organ nie może nałożyć na petenta żadnych kosztów związanych z postępowaniem w sprawie rozpoznania petycji. Ponadto organy władzy państwowej są zobowiązane do dbania, aby petent nie napotkał przeszkód w złożeniu petycji ze strony podmiotów prywatnych ${ }^{53}$. Następnie osoba składająca petycję ma roszczenie o przyjęcie petycji oraz rozpatrzenie jej. W piśmiennictwie wskazuje się, że aby instytucja petycji nie przybrała formy martwego przepisu, częścią składową prawa do petycji musi być też obowiązek organu do powiadomienia o rozpatrzeniu przesłanej petycji ${ }^{4}$. Problematyczne w tym kontekście staje się dokładne określenie, co powinno zawierać takie powiadomienie. FTK wskazuje, że treść powiadomienia powinna zawierać informację o tym, iż organ zapoznał się z treścią wniosku lub skargi oraz wskazywać

${ }^{50}$ C. Coelln, op. cit., s. 1329.

${ }^{51}$ Gesetz über die Befugnisse des Petitionsausschusses des Deutschen Bundestages, 19 VII 1975, BGBl. I, 1975, Nr. 85, s. 1921.

${ }^{52}$ W. Kluth, Art. 45c, w: Kommentar zum Grundgesetz, Hrsg. von H. Hofmann, H. Henneke, Köln 2014, s. 1310.

${ }^{53}$ C. Coelln, op. cit., s. 1332.

${ }^{54}$ J. Burmeister, op. cit., s. 78. 
sposób załatwienia sprawy. Samo potwierdzenie przyjęcia petycji jest w tym zakresie niewystarczające. Natomiast motywy, jakimi kierował się organ, nie są elementem koniecznym. Tak dalece idące żądanie co do treści powiadomienia, zdaniem FTK, prowadziłoby do nadinterpretacji art. 17 U.Z. ${ }^{55}$ Obowiązek organu do uzasadnienia swojej decyzji nie będzie natomiast stał w sprzeczności z art. 17 U.Z., jeżeli powinność ta będzie wypływać z innych norm prawnych. W tym kontekście można podać przykład regulaminu Bundestagu, który w $\$ 112$ ust. 3 zd. 2 przewiduje podanie uzasadnienia wydanego rozstrzygnięcia.

\section{Nadawca petycji jako podmiot uprawniony}

\subsection{Osoby fizyczne}

Podmiotami uprawnionym na mocy przepisów zgrupowanych w rozdziale pierwszym U.Z. zatytułowanym "Prawa podstawowe" są w pierwszej kolejności osoby fizyczne ${ }^{56}$. Poszczególne przepisy tego rozdziału, określając swój zakres podmiotowy, posługują się takimi zwrotami, jak "każdy" lub "Niemiec", rozróżniając tym samym prawa przysługujące wszystkim osobom fizycznym bądź grupie osób, do których na podstawie art. 116 U.Z. będą należały między innymi osoby posiadające obywatelstwo niemieckie. Podmiot uprawniony do wniesienia petycji, zgodnie z art. 17 U.Z., wyznacza słowo „każdy”. W związku z powyższym wskazuje się, że jest nim osoba fizyczna zarówno posiadająca obywatelstwo niemieckie, jak i obywatele innych krajów oraz bezpaństwowcy ${ }^{57}$. Jeśli chodzi o obcokrajowców, to miejsce zamieszkania nie ma większego znaczenia. Wskazuje się natomiast, że przedmiot petycji musi być w odpowiedni sposób tematycznie powiązany z niemiecką władzą państwową ${ }^{58}$. Jako przykład podaje się obcokrajowca mieszkającego za granica, ale wnoszącego petycję do niemieckiego organu w zakresie transgranicznej ochrony środowiska ${ }^{59}$.

Zakres podmiotowy prawa do petycji, co do zasady, nie jest też ograniczony wiekiem adresata i przysługuje także osobom nieposiadającym pełnej zdolności do czynności prawnych. W tym kontekście istotny jest

\footnotetext{
${ }^{55}$ Orzeczenie FTK z 22 IV 1953 r., sygn. 1 BvR 162/51, BVerfGE 2, 225, 230.

${ }^{56}$ R. Schmidt, Grundrechte, Bremen 2006, s. 25.

${ }^{57}$ H. Bauer, Art. 17, s. 1648.

${ }^{58}$ C. Coelln, op. cit., s. 1326.

${ }^{59}$ H. Bauer, Art. 17, s. 1649.
} 
psychofizyczny rozwój autora petycji, który musi być w stanie sformułować swoje żądania w sposób zrozumiały i przedłożyć je odpowiedniemu organowi państwa ${ }^{60}$.

Pewne ograniczenia strony podmiotowej prawa do petycji w stosunku do osób fizycznych wynikają z art. 17a U.Z., który został dodany do U.Z. w roku 1956. Ustęp pierwszy tego artykułu stanowi, że ustawy dotyczące służby wojskowej i zastępczej mogą w odniesieniu do osób pełniących służbę wojskową lub zastępczą ustanawiać ograniczenia: prawa podstawowego do swobodnego wyrażania i rozpowszechniania swoich poglądów w mowie, piśmie i obrazie (z art. 5 ust. 1, pierwsza część zdania 1 U.Z.), prawa podstawowego wolności zgromadzeń (z art. 8 U.Z.) i prawa do składania petycji ( $z$ art. 17 U.Z.), w zakresie zapewnienia prawa do zwracania się z pisemnymi prośbami lub zażaleniami wspólnie z innymi. Powyższy przepis formułuje ideę obywateli w mundurach, którzy pomimo pełnienia służby na rzecz państwa nie przestają być także obywatelami Republiki Federalnej Niemiec ${ }^{61}$. Celem tego przepisu jest jedynie zachowanie dyscypliny i funkcji sił zbrojnych oraz odsunięcie sił zbrojnych od sporów politycznych. W związku z tym organy władzy nie moga pozbawiać ani też limitować innych praw podstawowych nieujętych $w$ art. 17a U.Z., a gwarantowanych przez Ustawę Zasadniczą ${ }^{62}$. Adresatem tego przepisu sa, zgodnie z $§ 1$ ustawy o statusie prawnym żołnierzy ${ }^{63}$, żołnierze, do których zalicza się osoby odbywające służbę wojskową zarówno na podstawie powszechnego obowiązku wojskowego, jak i na podstawie dobrowolnego zobowiązania się. Paragraf 6 tejże ustawy wskazuje, że żołnierz ma takie same prawa obywatelskie jak każdy inny obywatel, jednocześnie zastrzegając, iż prawa żołnierza będą ograniczone w ramach potrzeb służby wojskowej poprzez uzasadnione obowiązki ustawowe. W związku z powyższym, opierając się na art. 17a U.Z., rozporządzenie o składaniu skarg w siłach zbrojnych ${ }^{64} \mathrm{~W} \S 1$ ust. 4 wprowadza zakaz składania przez żołnierzy petycji razem $z$ innymi osobami. Tej kategorii obywateli pozostawiono jednak możliwość składania petycji jednoosobowo. Ponadto art. 45d U.Z. ustanawia instytucję Pełnomocnika do Spraw Wojskowych w Bundestagu (Wehrbeauftragte des Bundestages). Jest to organ pomocniczy

\footnotetext{
${ }^{60}$ J. Burmeister, op. cit., s. 89.

${ }^{61}$ A. Guckelberger, Art. 17a, w: Kommentar zum Grundgesetz, s. 732.

${ }^{62}$ H. Bauer, Art. 17, s. 1666.

${ }^{63}$ Gesetz über die Rechtsstellung der Soldaten, 19 III 1956, BGBl. I, 1956, Nr. 11, s. 114.

${ }^{64}$ Wehrbeschwerdeordnung, 23 XII 1956, BGBI. I, 1956, Nr. 54, s. 1066.
} 
Bundestagu do sprawowania kontroli przez parlament nad wojskiem; ponadto sprawuje on funkcje organu, do którego żołnierze mogą wnosić petycje w celu ochrony ich praw podstawowych. Zgodnie z $\$ 7$ Ustawy o Pełnomocniku do Spraw Wojskowych Bundestagu ${ }^{65}$ każdy żołnierz ma prawo jednoosobowo zwrócić się do Pełnomocnika z petycją bez zachowania drogi służbowej. Urząd Pełnomocnika do Spraw Wojskowych został stworzony na wzór skandynawski i na poziomie federacji jest jedynym organem przypominającym polski urząd Rzecznika Praw Obywatelskich ${ }^{66}$. Obserwując statystyki, należy zauważyć, iż Pełnomocnik dość aktywnie bierze udział w ochronie praw konstytucyjnych żołnierzy. W roku 2017 do Pełnomocnika wpłynęło 2528 różnego rodzaju próśb i skarg skierowanych przez żołnierzy. Oczywiście, porównując te dane z latami wcześniejszymi, kiedy liczba ta sięgała powyżej 3000, osiągając w 2013 roku pułap 3770 petycji, można zaobserwować systematyczny spadek liczby składanych petycji. Jednak przytoczone dane statystyczne można wytłumaczyć spadkiem liczebności żołnierzy w aktywnej służbie wojskowej z $197880 \mathrm{w}$ roku 2012 do $178881 \mathrm{w}$ roku 201767. Z danych tych nie należy więc wyciągać wniosków o tendencjach spadkowych wskazujących na zmniejszenie się znaczenia tej instytucji.

Ograniczenia prawa do składania petycji mogą dotyczyć także skazanych odbywających karę pozbawienia wolności, wobec których zastosowano na podstawie $\S 31$ ustawy wprowadzającej do ustawy o sądownictwie ${ }^{68}$ zakaz kontaktów z innymi skazanymi lub z osobami spoza zakładu karnego ze względu na zagrożenie życia, zdrowia lub wolności innych osób ze strony organizacji terrorystycznej. W przypad$\mathrm{ku}$ zastosowania takiego zakazu nie jest możliwe między innymi tworzenie petycji zbiorowych wymagających kontaktu z innymi osobami69. FTK stwierdził brak naruszenia art. 17 U.Z. przez zastosowanie zakazu kontaktów wobec osadzonych w sytuacji, gdy osoby przebywające poza zakładem karnym, należące do organizacji terrorystycznej, przetrzymywały zakładnika, żądając uwolnienia rzeczonych osadzonych. Uzasadniając swoje rozstrzygnięcie, FTK wskazał, że co prawda z art. 17 U.Z. nie wynikają żadne ograniczenia prawa do petycji, jednak przepis ten

${ }^{65}$ Gesetz über den Wehrbeauftragten des Deutschen Bundestages, 26 VI 1957, BGBl. I, 1957, Nr. 28, s. 652.

${ }^{66}$ R. Schmidt-Radefeldt, Art. 45b, w: BeckOK Grundgesetz, s. 95, Nb. 1-5.

${ }^{67}$ Unterrichtung durch den Wehrbeauftragten Jahresbericht 2017, s. 95, http://dip21. bundestag.de/dip21/btd/19/007/1900700.pdf (dostęp: 23 IV 2018).

${ }^{68}$ Einführungsgesetz zum Gerichtsverfassungsgesetz, 27 I 1877, BGBl. I, S. 3546.

${ }^{69}$ C. Coelln, op. cit., s. 1335. 
nie konstruuje absolutnie chronionego roszczenia do natychmiastowego dalszego przekazania petycji do odpowiedniego adresata. Trybunał jednoznacznie wskazał, że prawo do petycji może być w tym kontekście ograniczone w zakresie celowego wykonania zakazu kontaktów. Ponadto Trybunał stwierdził, że prawo do petycji musi w takiej sytuacji ustąpić wartościom społecznym wyższego rzędu, do jakich należy życie ludzkie ${ }^{70}$. Ograniczenia tego typu w literaturze niemieckiej zwane są immanentnymi ograniczeniami konstytucyjnymi ${ }^{71}$.

Kolejne ograniczenie prawa do petycji wyłania się z treści art. 33 ust. 5 U.Z., który stanowi, że przepisy prawa dotyczące służby publicznej należy regulować i rozwijać przy uwzględnieniu tradycyjnych zasad obejmujących korpus urzędników państwowych. Postanowienia zacytowanego przepisu nie dotyczą jednak petycji niezwiązanych z czynnościami służbowymi podejmowanymi przez danego urzędnika ${ }^{72}$. Konkretne ograniczenia prawa do petycji wynikają z ustawy o urzędnikach federalny $\mathrm{ch}^{73}$ oraz odpowiedniego ustawodawstwa poszczególnych krajów związkowych. Zgodnie z § 125 ustawy o urzędnikach federalnych urzędnicy mogą składać wnioski i skargi w sprawach służbowych jedynie z zachowaniem drogi służbowej. Ponadto zgodnie z $\$ 67$ tego aktu zobowiązani są oni także do zachowania tajemnicy służbowej. W związku z tym wskazuje się, że informacje objęte tajemnicą służbową nie mogą być treścią petycji składanej przez samego urzędnika ani nie mogą być przekazane osobom trzecim w celu zawarcia przez nie tych informacji w treści petycji ${ }^{74}$. Nieprzestrzeganie drogi służbowej oraz niezachowanie tajemnicy służbowej może zakończyć się dla urzędnika postępowaniem dyscyplinarnym. Nie będzie to jednak miało wpływu na dopuszczalność rozpatrzenia samej petycji ${ }^{75}$.

\subsection{Osoby prawne}

Zdolność osób prawnych do bycia podmiotami praw podstawowych $\mathrm{z}$ rozdziału pierwszego U.Z. została określona w art. 19 ust. 3 U.Z., który

${ }^{70}$ Orzeczenie FTK z 1 VIII 1978 r., sygn. 2 BvR 1013, 1019, 1034/77, BVerfGE 49, 24, Nb. 33.

${ }^{71}$ H. Bauer, Art. 17, s. 1658.

${ }^{72}$ J. Burmeister, op. cit., s. 91.

${ }^{73}$ Bundesbeamtengesetz, 19 IX 1957, BGBl. I S., 1957, Nr. 51, s. 1337.

${ }^{74}$ H. Klein, op. cit., Nb. 125.

${ }^{75}$ Ibidem, Nb. 126. 
stanowi, że prawa podstawowe odnoszą się również do krajowych osób prawnych, o ile w swojej istocie mają one w stosunku do nich zastosowanie. Bezsprzecznie należy stwierdzić, że gwarancja prawa do petycji odnosi się także do tych podmiotów, przy czym konstytucja wskazuje tu wyraźnie na krajowe osoby prawne. Wnioskuje się na tej podstawie, że prawa do petycji nie gwarantuje się, co do zasady, osobom prawnym zarejestrowanym $\mathrm{w}$ innych krajach. Takie sformułowanie art. 17 oraz 19 ust. 3 U.Z. sprawia, że pozycja zagranicznych osób prawnych jest dość problematyczna ze względu na to, iż analizowane uprawnienie przysługuje osobom fizycznym będącym obcokrajowcami, ale już nie organizacjom zrzeszającym tychże obcokrajowców ${ }^{76}$.

Podmiotami, którym nie przysługuje prawo do składania petycji, są natomiast osoby prawne prawa publicznego. Wskazuje się, że w przypadku tych podmiotów brak jest stanu zagrożenia typowego dla praw podstawowych. W związku z tym, co do zasady, publiczne osoby prawne nie sa podmiotami uprawnionymi na podstawie praw podstawowych zawartych w rozdziale pierwszym U.Z., ale raczej są podmiotami zobowiązanymi ${ }^{77}$. Wyjątkami od tej zasady będą osoby prawne prawa publicznego, którym bezpośrednio przydzielono pewne dziedziny życia chronione przez konstytucję. Jako przykład podaje się tutaj publiczne rozgłośnie radiowe w kontekście art. 5 ust. 1 U.Z., który ustanawia wolność słowa i prasy oraz zakaz cenzury. Podmiotom tym przysługuje prawo do składania petycji jedynie wtedy, gdy służy to wsparciu przydzielonych im wolności. Przykładem może być tutaj uniwersytet publiczny, który składa do parlamentu petycję o zmianę ustawodawstwa naruszającego z perspektywy tego podmiotu zagwarantowaną mu w art. 5 ust. 3 U.Z. wolność artystyczną i naukową ${ }^{78}$.

Podobna sytuacja dotyczy gminy oraz związków gmin, którym co do zasady nie przysługują prawa podstawowe, a co za tym idzie, także prawo do petycji. Ustawa Zasadnicza w art. 28 ust. 2 nadaje jednak tym podmiotom pewną samodzielność zapewniającą gminom prawo do regulowania wszystkich spraw dotyczących wspólnoty lokalnej na własną odpowiedzialność w ramach przepisów prawnych. Takie prawo do samorządności zapewnia się również związkom gmin w ramach przewidzianego dla nich ustawowego zakresu zadań. Istnieją głosy

\footnotetext{
${ }^{76}$ C. Coelln, op. cit., s. 1327.

77 H. Klein, op. cit., Nb. 71.

${ }^{78}$ Ibidem, Nb. 72.
} 
wskazujące, że w granicach tak określonej autonomii gminy i ich związki mają możliwość składania petycji jako środka zaradczego w przypadku naruszenia ich prawa do samorządności ${ }^{79}$. Niemniej podkreśla się też, że gminy i ich związki nie mają potrzeby uciekania się do korzystania z instytucji petycji ze względu na to, iż posiadają one lepsze, mniej uciążliwe, możliwości dotarcia do osób decyzyjnych oraz brania udziału $\mathrm{w}$ procesie legislacyjnym ${ }^{80}$. Zaznacza się jednak, że nawet jeżeli nie można przyznać gminom prawa do składania petycji, to nie znaczy to, że nie mogą one zwracać się z prośbami lub pytaniami na przykład do rządu federalnego ${ }^{81}$.

\section{Rodzaje petycji a rodzaj adresata oraz nadawcy}

Artykuł 17 U.Z. wskazuje, że każdy może wnieść petycję indywidualnie lub wspólnie $\mathrm{z}$ innymi. W związku z tym od petycji indywidualnych należy odróżnić petycje zbiorowe, które mają inny cel i charakter, w zależności od rodzaju adresata oraz liczby podmiotów wnoszących je. Petycja składana przez większą liczbę osób wykracza poza tak zwaną „małą funkcję" prawa do petycjii ${ }^{82}$, przestając być jedynie ostatnioinstancyjnym instrumentem do rozwiązywania spraw beznadziejnych, który w literaturze określa się jako swego rodzaju ścianę płaczu dla obywateli $^{83}$. Petycje zbiorowe lub masowe rzadziej są używane do korygowania decyzji władzy publicznej w konkretnych przypadkach, a częściej skierowane są na korygowanie kierunku polityki państwa ${ }^{84}$. W związku z tym, wypełniając tzw. "dużą" funkcję petycji, można je analizować jako formę partycypacji obywateli w sprawowaniu władzy ${ }^{85}$. Wpływa ona na proces podejmowania decyzji w państwie, stając się przeciwwagą dla

${ }^{79}$ C. Langenfeld, Das Petitionsrecht, w: Handbuch des Staatsrechts der Bundesrepublik Deutschland, Bd. 3: Demokratie - Bundesorgane, Hrsg. von J. Isensee, P. Kirchhof, Heidelberg 2005, s. 274.

${ }^{80}$ M. Pagenkopf, Art. 17, w: Grundgesetz Kommentar, Hrsg. von M. Sachs, München 2018, Nb. 7.

${ }^{81}$ R. Rauball, Art. 17, w: Grundgesetz-Kommentar, Bd. 1, Hrsg. von I. von Münch, P. Kunig, München 1992, s. 948.

82 J. Krüper, op. cit., s. 1119.

${ }^{83}$ J. Burmeister, op. cit., s. 74.

${ }^{84}$ T. Würtenberger, Massenpetitionen als Ausdruck politischer Diskrepanzen zwischen Repräsentanten und Repräsentierten, "Zeitschrift für Parlaments Frage” 1987, Nr. 3, s. 383.

${ }^{85}$ J. Krüper, op. cit., s. 1119. 
szerokiej rzeszy lobbystów. Idąc dalej, można nawet upatrywać w takiej formie petycji podobieństwa do instytucji demokracji bezpośredniej ${ }^{86}$. Niemniej taki pogląd nie jest przyjmowany bez sceptycyzmu ${ }^{87}$. Wskazuje się, że chociaż petycja zawiera elementy plebiscytowe, to jednak nie można stwierdzić, iż jest jedną $z$ form sprawowania władzy przez obywateli $^{88}$. Co prawda, zgodnie z art. 20 ust. 2 zd. 2 U.Z., władza państwowa jest sprawowana przez Naród w formie wyborów i plebiscytów, lecz, jak wskazuje się w literaturze przedmiotu, masowym petycjom, żeby je zaliczyć do formy sprawowania władzy w ramach demokracji bezpośredniej, brakuje pewnej dozy państwowego zorganizowania, która charakteryzuje referenda. Ze względu na odformalizowany charakter prawa do petycji nie można też stwierdzić, aby przedłożona petycja podpisana przez znaczącą liczbę osób była odwzorowaniem zdania całego narodu albo jego przeważającej części. W porównaniu z masowymi petycjami referendum umożliwia wypowiedzenie się wszystkim obywatelom i jest w stanie dać dokładniejszy obraz nastrojów panujących w społeczeństwie, a nie jedynie przedstawić zdanie dobrze zorganizowanej i aktywnej politycznie części społeczeństwa ${ }^{89}$. Niemniej jednak należy wskazać, że instytucja ta jest dość popularną formą partycypacji społeczeństwa, za czym przemawiają dane statystyczne,tj. liczba petycji składanych co roku do Bundestagu ${ }^{90}$.

Należy zauważyć tė̇, że prawo do petycji wypełnia pewną lukę w U.Z., w której brakuje instytucji demokracji bezpośredniej, takich jak na przykład ludowa inicjatywa ustawodawcza czy referendum, i w której główny nacisk kładzie się na demokrację pośrednią w postaci wyborów do Bundestagu. W tym kontekście na szczególną uwagę zasługuje tzw. petycja publiczna do Bundestagu, która to instytucja została wprowadzona w 2005 r. Jest ona wzorowana na petycji do regionalnego parlamentu Szkocji ${ }^{11}$. Ma formę elektroniczną i jest przewidziana dla składania próśb i skarg do Bundestagu, których treść jest odpowiednia do publicznej

${ }^{86}$ A.Jungherr, E-Petition in Deutschland:Zwischen niedrigschwelligem Partizipationsangebot und quasi-plebiszitärer Nutzung, "Zeitschrift für Parlamentsfragen" 2011, Nr. 3, s. 525.

${ }^{87}$ J. Burmeister, op. cit., s. 82.

${ }^{88}$ T. Würtenberger, op. cit., s. 388.

${ }^{89}$ Ibidem, s. 389.

${ }^{90}$ Die Tätigkeit des Petitionsausschusses des Deutschen Bundestages im Jahr 2016, BT-Drs. 18/12000, s. 81, http://dipbt.bundestag.de/dip21/btd/18/120/1812000.pdf (dostęp: 23 IV 2018).

${ }^{91} \mathrm{H}$. Bauer, Demokratisch inspirierte Petitionsrechtsmodernisierungen, w: Verfassungsstaatlichkeit im Wandel. Festschrift für Thomas Würtenberger zum 70. Geburtstag, Hrsg. von D. Heckmann, R. Schenke, G. Sydow, Berlin 2013, s. 641. 
debaty ze względu na interes publiczny. Wyklucza to rozpatrzenie w tej formie petycji w sprawach o charakterze osobistym. Po jej złożeniu oraz zakwalifikowaniu przez Komisję Petycji jako petycji publicznej jest ona dostępna za pośrednictwem specjalnego portalu internetowego dla każdej zainteresowanej osoby, która po zarejestrowaniu na portalu może elektronicznie podpisać petycję, a także ma możliwość komentowania wniesionych petycji. Wskazuje się, że celem stworzenia tej formuły wnoszenia próśb i skarg było wzmocnienie demokracji pośredniej w Federalnej Republice Niemiec, polepszenie komunikacji pomiędzy obywatelami a parlamentarzystami oraz włączenie obywateli w proces podejmowania decyzji ${ }^{92}$. Inicjatywa ta $\mathrm{z}$ wielkim sukcesem wpłynęła na transparentność postępowania w sprawie rozpatrzenia petycji, stanowiąc filar politycznej partycypacji obywateli ${ }^{93}$. Ma to także odwzorowanie w danych statystycznych, które są optymistyczne i wskazuja, że ten rodzaj petycji zyskuje na znaczeniu. Liczba zarejestrowanych użytkowników portalu Komisji do Spraw Petycji przekroczyła dwa miliony, a drogą elektroniczną złożono 3698 petycji, co stanowi 33\% wszystkich petycji złożonych w 2016 r. do Bundestagu ${ }^{94}$. Bez wątpienia, elektroniczna petycja wpisuje się w koncepcję e-demokracji, obejmującej także e-administrację, która zbliża obywatela do państwa i jego instytucji ${ }^{95}$.

\section{Podsumowanie}

Należy zauważyć, że instytucja petycji ustanowiona w art. 17 U.Z. obejmuje bardzo szeroki zakres podmiotów, zarówno jeśli chodzi o petentów, jak i adresatów petycji. W zależności od rodzaju petenta i rodzaju

${ }^{92}$ Bericht des Petitionsausschusses, Bitten und Beschwerden an den Deutschen Bundestag, Die Tätigkeit des Petitionsausschusses des Deutschen Bundestages im Jahr 2005, BT-Drs. 16/2500, s. 10, http://dip21.bundestag.de/dip21/btd/16/025/1602500. pdf (dostęp: 23 IV 2018).

${ }^{93}$ H. Bauer, Partizipation durch Petition - Zu Renaissance und Aufstieg des Petitionsrechts in Deutschland und Europa, "Die Öffentliche Verwaltung” 2014, Nr. 11, s. 459.

${ }^{94}$ Bericht des Petitionsausschusses, Bitten und Beschwerden an den Deutschen Bundestag, Die Tätigkeit des Petitionsausschusses des Deutschen Bundestages im Jahr 2016, BT-Drs. 18/12000, s. 6, http://dipbt.bundestag.de/dip21/btd/18/120/1812000. pdf (dostęp: 23 IV 2018).

${ }^{95}$ Bericht des Petitionsausschusses, Bitten und Beschwerden an den Deutschen Bundestag, Die Tätigkeit des Petitionsausschusses des Deutschen Bundestages im Jahr 2012, BT-Drs. 17/13660, s. 8, http://dipbt.bundestag.de/doc/btd/17/136/1713660.pdf (dostęp: 23 IV 2018). 
adresata przybiera ona różny charakter. Z perspektywy petentów art. 17 U.Z. daje im narzędzie, które jest dla nich powszechnie dostępne i łatwe w użyciu, o czym świadczą dane statystyczne Bundestagu ${ }^{96}$. Wskazują one ponadto, że petycja jest bardzo dobrą formą komunikacji obywateli z organami państwa. Znajduje szerokie zastosowanie zarówno jako narzędzie ochrony prawnej jednostki, jak i uzupełnienie form partycypacji obywateli w kształtowaniu kierunku rozwoju państwa. Dodatkowo zastosowanie nowoczesnych technologii perspektywicznie stwarza możliwość dalszego rozwoju petycji jako metody demokratycznego współdecydowania przez obywateli o istotnych dla państwa zagadnieniach, będącej zalążkiem swoistej e-demokracji.

Z punku widzenia organów państwa petycja daje możliwość nie tylko skorygowania błędów przez nie popełnionych, ale też sprawdzenia nastrojów społecznych; ponadto daje podstawy do prognozowania kierunków rozwoju i ustalania przyszłych problemów. Petycje składane przez obywateli mogą być również źródłem inspiracji zmian na wszystkich szczeblach państwa.

Bazując na powyżej opisanych doświadczeniach niemieckiej nauki prawa, można wywnioskować, że z perspektywy organów władzy publicznej petycja nie powinna być postrzegana jedynie przez pryzmat obowiązku jej rozpatrzenia. Zapoznanie się przez organ z petycją i wyciągnięcie z niej wniosków powinno leżeć także w interesie dobrze działającej administracji publicznej. W związku z tym, otrzymując petycję, organ powinien przede wszystkim zwracać uwagę na jej treść, a nie na to, czy danemu podmiotowi przysługuje do niej prawo. Urzeczywistnienie funkcji petycji jest możliwe tylko dzięki temu, że petycja ma szeroki zakres podmiotowy, co odnosi się zarówno do uprawnionych do jej złożenia, jak i zobowiązanych do jej rozpatrzenia.

\section{THE SUBJECTIVE SCOPE OF RIGHTS TO PETITION IN GERMANY}

\section{Su m mary}

The subject of this article is the right to petitions specified in Article 17 of the Basic Law of the Federal Republic of Germany. This provision regulates the individual's

${ }^{96}$ Bericht des Petitionsausschusses, Bitten und Beschwerden an den Deutschen Bundestag, Die Tätigkeit des Petitionsausschusses des Deutschen Bundestages im Jahr 2016, BT-Drs. 18/12000, s. 81, http://dipbt.bundestag.de/dip21/btd/18/120/1812000. pdf (dostęp: 23 IV 2018). 
right to address requests and complaints to public authorities. This publication contains an analysis of this institution with regard to entities that are entitled to exercise this right, as well as entities obliged to consider submitted petitions.

The author begins the analysis of the indicated institution be reviewing the evolution of the historical right to petition, which has evolved from the institution of supplication known in ancient Rome. He indicates changes in the subjective scope of the right to petitions, focusing on the achievements of German constitutionalism in the 19th century.

Next, the current regulation that guarantees the right to petition in Germany in its normative environment is presented. The public authorities that are the addressees of the petition have been analysed, and the scope of duties associated with receiving a complaint or request indicated. Furthermore the author describes particular types of entities that are guaranteed the right to submit petitions under the Basic Law of the Federal Republic of Germany. In this respect, various kinds of restrictions of this right, depending on the type of the petitioner, are identified.

The last part of the work contains the characteristics of various forms of petitions due to the type of author and the addressee. Various functions which currently are fulfilled by the institution of petitions were subjected to analysis. In this context, a distinction was made between individual petitions and collective petitions, taking into account their subject matter and the aims intended by the petitioner. The author also shows the future possibility of a development of the discussed institution, describing the public petition to the Bundestag, which has an electronic form.

Keywords: petition - subjective scope - Germany 